\title{
O PROBLEMA DA HYBRIS NA FILOSOFIA GREGA ANTIGA
}

\author{
Fábio Candido dos Santos* \\ (Faculdades Integradas Hélio Alonso)
}

\begin{abstract}
RESUMO: O objetivo deste trabalho é o de mostrar como a filosofia grega antiga tratou do fenômeno humano da hybris - a desmedida - a partir das considerações de Platão, Aristóteles e Heráclito, pensadores que se debruçaram sobre a questão. Nesta perspectiva, serão apresentadas as noções por meio das quais cada um dos filósofos supracitados combateu o problema, partindo da apresentação de um métron natural (physei) - uma medida - que pudesse extinguir a hybris e ser tomada como critério ontológico da ação do homem em geral. Palavras-Chave: Hybris; métron; mesótēs; lógos; homologeīn.
\end{abstract}

\section{THE PROBLEM OF HYBRIS IN ANCIENT GREEK PHILOSOPHY}

ABSTRACT: The purpose of this paper is to show how ancient Greek philosophy dealt with the human phenomenon of hybris - the démesure - from the considerations of Plato, Aristotle and Heraclitus, thinkers who have addressed the issue. In this perspective, the notions by which each of the above-mentioned philosophers countered the problem will be presented, starting from the presentation of a natural métron (physei) - a measure - that could extinguish hybris and be taken as an ontological criterion of man's action in general.

KEYWORDS: Hybris; métron; mesótēs; lógos; homologeìn.

\section{A PROVENIÊNCIA FILOSÓFICA DA QUESTÃo DA HYBRIS ${ }^{1}$}

A filosofia grega antiga herda da tradição mítica a crença na existência de uma ordem que governa e dispõe o real. Na época de Homero e Hesíodo - para citar apenas os maiores poetas helênicos - acreditava-se que esta configuração era dada pelos deuses, que, como se sabe, não criavam, limitando-se, todavia, a organizar o kósmos e a guardar sua ordem, punindo tudo aquilo que a ameaçasse. A sentença de Anaximandro, preservada por Simplício,

\footnotetext{
*E-mail: fahbio@msn.com

${ }^{1}$ Polissêmico, como ficará claro ao longo deste artigo, o termo hybris, contudo, remete a um núcleo semântico e filosófico - a noção de desmedida - que amarra e organiza todos as versões do fenômeno, mesmo que esta constatação se dê apenas indiretamente. É o que se pode depreender das possibilidades expostas para a hybris no verbete dedicado à palavra no Léxico greco-inglês de Liddell e Scott. Entre as versões apresentadas - sempre ligadas às obras nas quais ocorrem - estão (1) "violência arbitrária emergindo do orgulho da força ou da paixão, insolência; (2) "Luxúria", "indecência", "violência animal", "ultraje", "violação", "estupro"; (3) "No direito [law], um termo cobrindo todas as mais sérias injúrias [injuries] feitas a uma pessoa". Cf. LIDDELL, Henry George; SCOTT, Robert. A greek-english lexicon. Oxford, Claredon Press: 1996, p. 1841. Grifos dos autores.
} 
na Física ${ }^{2}$, e tida como o mais antigo escrito filosófico, exemplifica com precisão esse legado mítico apropriado pelo pensamento filosófico:

Princípio dos seres... Ele disse (que era) o ilimitado... Pois donde a geração é para os seres, é para onde também a corrupção se gera segundo o necessário; pois concedem eles mesmos justiça e deferência uns aos outros pela injustiça, segundo a ordenação do tempo.

Assim como nos textos de Hesíodo e Homero, as primeiras considerações filosóficas giravam em torno da ideia de ordem e de harmonia, que transcendem e organizam os entes, provendo-lhes o ser e o não-ser. No fragmento de Anaximandro, encontram-se, com efeito, as míticas noções de díke e adikía, que dizem respeito à manutenção daquela estrutura, além das ideias de arché, o princípio ou a origem, e de Chrónou, o tempo, como o ordenador daquela configuração ontológica. O que diferencia mito e filosofia, contudo, é fato de à crença nos deuses como fundamento se seguir a busca por uma arché cuja descoberta possibilitaria o desvelamento da ordem que dispõe o mundo aos olhos do homem. A ideia de ordem e harmonia transcendente, ou seja, de existência de um fundamento último do real, contudo, permanece e só se "resolve" com a metafísica de Platão e de Aristóteles.

Nesta perspectiva, o problema da oposição entre métron $^{3}$ e hybris não se modifica, sendo apropriado pela filosofia, embora sem as tintas morais ou jurídicas encontradas entre os poetas antigos. Métron será entendido pela filosofia de duas formas. A primeira diz respeito à ordenação do real e a segunda a cada ente especificamente, ligado, ontologicamente, àquela. A medida da realidade é sua ordem, ao passo que cada ente, ao se ligar a ela, deve, obrigatoriamente, cuidar da sua própria, entendida como o seu ser, "doado", a propósito, por aquela estrutura transcendente. Entre o métron da realidade do real e o dos entes, há, porém, uma ponte, que será discutida principalmente por Heráclito. A hybris, com efeito, nada será além da negligência com a transcendência e, assim, com o próprio ser daquele que a realiza. No caso específico do homem - o lógos, aquele caráter que o diferencia dos demais entes.

Se no discurso mítico a questão apresentava um viés essencialmente moral que transbordava para outras áreas, na filosofia ganha contornos ontológicos e, assim, se apresenta como a origem de todos as outras perspectivas precedentes. Quando, por exemplo, Platão fala em metafísica, alude a uma instância transcendente que governa o mundo, provendo-lhe a medida, ou seja, o métron, cujo acesso deve ser feito por meio do lógos, a medida - o ser - do homem. O oposto para o filósofo, ou seja, pautar-se pelos prazeres dos sentidos, seria deixarse dominar pela hybris e afastar-se daquilo que é essencialmente próprio do homem. No Filebo, Platão faz Protarco defender justamente essa ideia: "pois não se encontraria, segundo penso, nada mais naturalmente desmedido (ametrōteron) que o prazer e alegrias excessivas, nem nada mais comedido (emmetrōteron) que a inteligência e o conhecimento" ". De fato, a questão da relação dicotômica entre métron e hybris perpassa todo o pensamento grego na medida em que busca determinar o ser do homem a partir do Ser entendido como o métron, ou seja, a realidade do real. Desta forma, a pergunta pela medida e pela desmedida se

\footnotetext{
${ }^{2}$ Física, 24, 13. Cf. HERÁCLITO. Fragmentos contextualizados. Trad. Alexandre Costa. São Paulo, Odysseus, 2012.

${ }^{3}$ A palavra métron traz menos dificuldades de tradução que hybris, tradicionalmente oposta àquela, uma vez que menos rica em significados. Basicamente, pode-se dizer que métron remente a algo a partir do qual algo é medido, ou seja, a medida ou mesmo ao que é medido (espacialmente). No entanto, no verbete dedicado ao vocábulo do Léxico greco-inglês de Liddell e Scott, há uma versão que se mostra mais fundamental e condizente com o que se discute neste artigo: medida no sentido de "limite", ou seja, aquilo que não pode ser ultrapassado. Cf. LIDDELL, Henry George; SCOTT, Robert. A greek-english lexicon. Oxford, Claredon Press: 1996, p. 1123. ${ }^{4}$ Filebo, 65d.
} 
constitui, com efeito, como a indagação que motivou o desenvolvimento do pensamento filosófico grego: o que é o Ser?

Entre os filósofos gregos, a questão da hybris é tematizada mais profundamente por Heráclito, Platão e Aristóteles, que, com efeito, se dividiram quanto à abordagem do problema. Enquanto Heráclito explorou a questão de um ponto de vista essencialmente ontológico-cosmológico, Platão e Aristóteles a entenderam primordialmente de maneira psicológica, ética e política, encontrando na hybris o fundamento das paixões e a principal ameaça a um padrão lógico para a ação. No fundo, e apesar das perspectivas distintas, o conceito de lógos atravessa e estrutura as considerações dos três pensadores acerca do métron e de sua possibilidade de ruptura: hybris.

\section{PLATÃo}

A análise de Platão sobre o problema da hybris se concentra no Fedro e nas Leis, derradeira obra do filósofo ateniense. A questão ainda pode ser identificada em outros trabalhos do mestre de Sócrates, como no Crítias $^{5}$, mas apenas nas duas obras supracitadas é possível observar com profundidade a amplitude da questão no pensamento de Platão.

No Fedro, e ao investigar a natureza do amor, Platão mostra, dicotomicamente, e como é característico de sua filosofia, que o homem é governando por dois princípios. Um é o desejo do prazer e o outro, o do bem, fundado no lógos. O caráter humano oscila de acordo com a predominância de um dos dois na alma: "quando prevalece o gosto racional do bem e esse nos dirige", explica Platão, "recebe o nome de sōphrosyne $\bar{e}^{-6}$; porém, quando é o gosto irracional que nos arrasta para os prazeres, e impera em nós, hybris é o nome dado a tal governo"7. A hybris, com efeito, nada mais é do que o desrespeito humano à sua própria estrutura ontológica - o exercício do lógos - na sucumbência ao poder e à sedução dos prazeres.

De fato, na raiz (filosófica) da sōphrosyne, encontra-se o lógos, cuja relação é discutida pelo filósofo com mais profundidade no Górgias ${ }^{8}$ e na República ${ }^{9}$, obras tradicionalmente listadas como anteriores ao Fedro ${ }^{10}$. Em ambas, a sōphrosynē é apresentada

\footnotetext{
${ }^{5}$ Platão, no Crítias, se limita a tentar recuperar o sentido mítico-religioso ao interpretar a Guerra do Peloponeso por meio do mecanismo de castigo da hybris, afastando-se do aspecto filosófico que só será abordado nas Leis e no Fedro. Cf. CASAS, Javier Picón. La Noción de "Hybris" en el Critias de Platón. Areté - Revista de Filosofía, Salamanca, Vol. XX, No 1, p. 76, 2008.

${ }^{6}$ A noção de sōphrosynē aparece contraposta à de hybris nesta passagem e se mostra como uma "alternativa" à ideia de métron. Liddell e Scott entendem a sōphrosynē como oposta à hybris no sentido de luxúria ou indecência - exatamente o que Platão ambicionava no trecho em questão. No verbete dedicado à sōphrosyne, ampliam a noção ao encontrarem nela os sentidos de (1) "retidão [soudness of mind] prudência, discrição [discretion]", "sanidade (em oposição à manía)"; (2) "moderação nos desejos sensuais, autocontrole e temperança"; (3) em um sentido político, uma forma moderada de governo". Na passagem em questão, na qual a sōphrosynē é oposta à hybris por Platão, o sentido (2) se mostra mais adequado e realmente próximo a uma ideia de medida enquanto limite, uma vez que moderação e temperança se mostram basicamente como posturas de observância de algo como um meio-termo ou justamedida. Cf. LIDDELL, Henry George; SCOTT, Robert. $A$ greek-english lexicon. Oxford, Claredon Press: 1996, p. 1841 (para o verbete de hybris no qual a relação com sōphrosynēe é tematizada) e p. 1751 (para o verbete sōphrosynē). Grifos dos autores.

${ }^{7}$ Fedro, 237e-238a.

${ }^{8}$ No Górgias, Platão vê a sōphrosynē como a principal condição à consecução da eudaimonía: "é forçoso que o indivíduo temperante (sōphrona), sendo, como vimos, justo (díkaion), corajoso e pio, seja protótipo da bondade (agathón); o homem bom fará bem e com perfeição tudo o que faz, e quem vive bem e feliz é bem aventurado (eudaimona)". Cf. Górgias, 507c.

${ }^{9} \mathrm{Na}$ República, a sōphrosyne mantém sua importância como uma das quatro virtudes de Platão, mas, no que diz respeito a uma hierarquia, cede seu lugar à dikaiosyne (justiça), como a virtude mais elevada. Cf. PLATÃO, República, 429e-433c.

${ }^{10}$ Cf. ABBAGNANO, Nicola. História da Filosofia. Volume. 1. Trad. António Borges Coelho, Franco de Sousa e Manuel Patrício. Lisboa: Editorial Presença, 1999, p. 99.
} 
como um princípio de autogoverno regulado pelo lógos com vistas à dikaiosyne, mote, a propósito, da obra máxima do filósofo ateniense. Aqui Platão retoma a tradição mítica ao aproximar uma ideia de medida à de justiça, sendo esta última, com efeito, reflexo da observância daquela. Afinal, o indivíduo temperante é justo, pois segue aquilo que o diferencia dos outros entes, exercendo sua humanidade, isto é, o lógos. De acordo com Platão na República, "a sōphrosynē se assemelha a uma harmonia"11 e "é uma espécie de ordenação, e ainda o domínio de certos prazeres e desejos"12. A hybris, ao contrário, se apresenta ao homem como a possibilidade de destruição de seu ser ao fomentar o prazer em lugar do lógos na condução de suas ações.

Entretanto, o problema da identificação platônica do lógos com o métron por meio da sōphrosynē encontra-se na rigidez de seu caráter. Para Platão, como já preconizava o "pai" Parmênides, a ênfase sempre recai sobre o espiritual, o metafísico, uma vez que o físico é, em síntese, o erro, a fonte de engano. No Fédon, o filósofo, ao tratar da sōphrosynē, radicaliza esta posição ao indagar sobre a participação da noção de temperança no caráter do amante da sabedoria: "E a sōphrosynē, o que todo mundo chama de temperança: não deixar-se dominar pelos apetites, porém desprezá-los e revelar moderação, não será qualidade apenas das pessoas que em grau eminentíssimo desdenham do corpo e vivem para a filosofia?"13.

No livro II das Leis, obra na qual revisa muitos pontos de sua primeira utopia política - a República -, Platão aponta para uma consequência ao mesmo tempo necessária e nefasta do predomínio da hybris nas almas dos indivíduos: "um homem que traga consigo nada além de injustiça e hybrin: será que eu não consigo te convencer do fato de que quem vive dessa forma não é obviamente eudaímona (feliz), mas profundamente infeliz?"14. A "felicidade" do homem de Platão é a realização de seu ser, a saber, a orientação pelo lógos. Desrespeitar esta regra ontológica é cair em hybris e ser, definitivamente, infeliz.

No contexto das Leis, o interesse de Platão é no coletivo, pois a obra se constitui, essencialmente, por uma análise dos negócios da pólis. Afinal, se os homens não se deixarem levar pelas paixões e, ao contrário, conduzirem-se pelo lógos, uma cidade mais harmônica e justa será a consequência imediata desta postura comunitária. Acima de tudo isso, obviamente, figurariam os deuses, ciosos das ações humanas, e sempre dispostos a punir violações do direito. Platão, de fato, não perde a ligação com os antigos e apresenta, ainda nas Leis, uma fundamentação religiosa do problema. No Livro IV, e após subverter a sentença de Protágoras ${ }^{15}$ e defender a tese de que "a divindade é a medida de todas as coisas" ${ }^{16}$, o filósofo enumera as implicações de uma conduta não prudente para a pólis:

\footnotetext{
Aquele que se enche de soberba, [...] e que através desse orgulho associado à juventude e à loucura tem sua alma inflamada pela hybris, [...] é abandonado e preterido pelo deus [...] e por seu pavoneamento desatinado mergulha todos na confusão $^{17}$.
}

O problema da hybris no pensamento de Platão é, no fundo, o problema da negligência de uma ordem psicológica - do necessário domínio do lógos sobre as paixões - e, por extensão, de sua difusão política, que colocaria a comunidade a perder, pois, se os homens pautassem suas ações por seus prazeres, não haveria possibilidade de formação social sólida e, dessa forma, estaria instalado o caos que poria a perder o próprio homem. Visando a solidificar sua

\footnotetext{
${ }^{11}$ A República, 431e.

${ }^{12}$ A República, 430e.

${ }^{13}$ Fédon, 68d.

${ }^{14}$ As Leis, 661e.

15 Ibid.

${ }^{16}$ As Leis, 716c.

${ }^{17}$ As Leis, 716a.
} 
posição, Platão vincula o político ao religioso com o objetivo de reforçar o papel das divindades na observância dos atos individuais e coletivos do homem, exortando-o a manterse sempre em sua medida, ou seja, no lógos.

\title{
3. ARISTÓTELES
}

Aristóteles mantém a posição de Platão acerca do problema da hybris ao identificar no fenômeno, a exemplo do antigo mestre, uma ameaça à natureza racional do homem. $\mathrm{O}$ estagirita, contudo, acentua o aspecto ético da questão e suas implicações políticas a partir de uma discussão mais profunda sobre a formação do homem. Não por acaso a definição de hybris de Aristóteles aparece nas Virtudes e vícios, obra que compõe os escritos éticos do Corpus aristotelicum. De acordo com o estagirita, "hybris é a incorreção que faz os homens buscarem prazeres para eles mesmos enquanto leva outros à desgraça" ${ }^{18}$. O fenômeno é visto, como em Platão, em conexão com os prazeres e, assim, distante do lógos, devendo ser eliminado para que o homem, em particular, e a comunidade, em geral, possam prosperar.

No livro V da Política, o estagirita apresenta a contraposição da hybris ao lógos de forma direta ao tratar das motivações do ódio e da cólera: "sob sua influência, o ataque se faz mais veemente, pois a paixão não calcula (e é sobretudo a hybris que faz os homens se abandonarem aos arrebatamentos dela)" ${ }^{\prime 19}$. Ao defender a distinção e a consequente oposição entre lógos e páthos, Aristóteles entende o fenômeno em questão como uma espécie de desatino que afasta o homem do pensamento e da reflexão. Nesta perspectiva, o estagiria lembra, em outra passagem da mesma obra, que Hipodâmos, supostamente o primeiro nãopolítico a discutir uma forma de constituição, teria defendido a existência de apenas "três tipos de leis porque os fatos delituosos que suscitam ações na justiça são em número de três: — hybris, danos e homicídios" ${ }^{20}$. A concepção jurídica do estagirita encontra fundamento na psicológica, uma vez que apenas pessoas "tomadas" pela hybris poderiam transgredir regras.

Na Ética a Nicômaco, Aristóteles não analisa o fenômeno diretamente, mas deriva, muito provavelmente, a doutrina do mesótēs ${ }^{21}$, constituinte da aretē, do problema da hybris. No livro II, onde investiga a relação entre mesótēs e aretē com o objetivo de esclarecer a configuração desta última, afirma que:

\begin{abstract}
a virtude é uma disposição em agir de uma maneira deliberada, consistindo em uma mediedade relativa a nós, racionalmente determinada e como a determinaria o homem prudente. Mas é uma mediedade entre dois vícios, um por excesso e outro por falta; e [é ainda uma mediedade] que em certos vícios esteja abaixo e outros acima do que "é necessário" no domínio das afecções tanto quanto das ações, ao passo que a virtude descobre e escolhe a posição média. É porque na ordem da substância e da definição exprimindo a quididade, a virtude é uma mediedade, enquanto na ordem da excelência e do perfeito, é um ápice ${ }^{22}$.
\end{abstract}

Por mais que não se utilize da palavra hybris, Aristóteles sugere que os excessos, ou seja, rupturas com algum tipo de medida, são prejudiciais ao exercício da aretē e, por extensão, da possibilidade de realizar adequadamente aquilo que é próprio do homem - o lógos. Afinal,

\footnotetext{
${ }^{18}$ Virtudes e vícios, $1251 \mathrm{a}$.

${ }^{19}$ Política, 1312b25-30.

${ }^{20}$ Política, 1268a16-18.

${ }^{21} \mathrm{O}$ termo mesótēs remete à "posição central" e ao "medium, comunicando entre dois extremos", de acordo com Liddell e Scott, e, desta forma, mostra como, indiretamente, se relaciona ao antagonismo hybris - métron no sentido em que se apresenta como uma posição de (justa)medida ou mediedade (métron) em detrimento do excesso ou da falta (hybris). Cf. LIDDELL, Henry George; SCOTT, Robert. A greek-english lexicon. Oxford, Claredon Press: 1996, p. 1108. Grifo dos autores.

${ }^{22}$ Ética a Nicômaco, 1107a1-7.
} 
agir de acordo com o lógos é, no fundo, encontrar-se sempre no meio-termo, isto é, na medida do homem excelente, uma vez que a mediedade é a quididade da virtude. Sucumbir ao vício, ao arrebatamento das páthē, ao contrário, representaria cair em extremos que levariam a uma vida desmedida e, assim, em desacordo com o lógos. Aqui já é possível entrever na filosofia de Aristóteles uma proximidade entre métron e lógos e hybris e páthos, que, no fundo, remeteria às especulações dos primeiros pensadores gregos.

No trecho da Ética supracitado, Aristóteles reforça, de um ponto de vista estritamente ético, o que já asseverava de uma perspectiva psicológica: a hybris é motivada pelos prazeres $^{23}$, que, ao se chocarem com os ditames do lógos, impossibilitam a realização da aretē, concorrendo para a diminuição ou mesmo a eliminação da "humanidade" do homem. Aristóteles também defende esta configuração no espectro político, como uma passagem do livro IV da Política, ainda alusiva à doutrina da mesótēs, o demonstra:

\footnotetext{
Se, com efeito, o que dissemos na Ética é exato, a saber, que a vida feliz é aquela que se persegue conforme à virtude, e esta, sem entraves, e que a virtude é uma mediedade, se segue necessariamente que a vida que se mantém no meio termo é a melhor, quero dizer um meio termo que cada indivíduo seja capaz de atingir. E esses mesmos princípios de determinação devem necessariamente também se aplicar à excelência ou à perversão de um estado e de uma constituição, a constituição sendo, de qualquer forma, a vida do estado ${ }^{24}$.
}

Na maioria das sociedades, ocorre uma polarização entre pobres e ricos. Segundo Aristóteles, estes não aceitam se deixar governar facilmente enquanto aqueles só saberiam servir, originando uma comunidade de servos e senhores - falta e excesso - e não de homens livres, o meio termo entre as duas classes. Para resolver o problema, o estagirita sugere que o governo seja da "classe média", espécie de personificação da mediedade social, isto é, daqueles cidadãos que não sejam nem ricos nem pobres. De acordo com a teoria do pensador de Estagira, a cidade, para ser boa, deveria, a exemplo do indivíduo, pautar-se pelo governo do meio termo, ou seja, do métron.

A teoria da mesótēs encontra-se no fundo das concepções políticas, éticas e psicológicas de Aristóteles, assentando-se, com efeito, no caráter distintivo do homem - o lógos ${ }^{25}-$, que empresta a ele o métron para uma boa vida, ou seja, o fundamento de realização da eudaimonía. A hybris, neste cenário, conspira contra o próprio ser do homem, pondo a perder não apenas o seu caráter individual, mas, sobretudo, a possibilidade de organização coletiva e de seus desdobramentos sociais.

\section{HERÁCLITO}

Heráclito é o pensador mais antigo a discutir filosoficamente o problema da hybris e também aquele no qual se fundamentam as análises posteriores da questão, como as de Platão e de Aristóteles. Diferentemente destes, que reduziram o exame da discussão acerca do fenômeno ao homem, o efésio, contudo, tentou observá-lo ainda mais originariamente, ou seja, a partir da physis e do kósmos. Apesar de toda a argumentação que depõe contra a interpretação sistematizante dos fragmentos de Heráclito, é possível esboçar uma teoria heraclítica da hybris. Pelo menos seis aforismos do efésio tornam o empreendimento possível. São eles o 43, que apresenta explicitamente o posicionamento de Heráclito acerca do fenômeno, o 1, o 30, o 45, o 50 e o 94.

\footnotetext{
${ }^{23}$ Ética a Nicômaco, $1104 b 9$.

${ }^{24}$ Política, $1295 b$.

${ }^{25}$ Política, 1180a.
} 
No fragmento 43, preservado por Diógenes Laércio ${ }^{26}$ nas Vidas e Doutrinas dos Filósofos Ilustres, lê-se que "mais do que o incêndio, é necessário apagar a hybris". O tradutor utilizado aqui Alexandre Costa preferiu "não traduzir o termo hybris por ser frequente no vocabulário filosófico" 27 . No entanto, as versões mais comuns para os vernáculos modernos apenas confirmam o que foi exposto até o momento. Presunção ${ }^{28}$, desmedida $^{29}$, insolência $^{30}$ e insulto ${ }^{31}$ são alguns exemplos das traduções mais comuns do termo. Como já discutido anteriormente, a interpretação da palavra e, por extensão, da estrutura do fenômeno por desmedida seria, no atual contexto, mais adequada por preservar em si o status de ruptura com o métron, a medida, o que não acontece nas demais possibilidades de tradução, a despeito de sua indiscutível precisão. Isoladamente, é necessário admitir a dificuldade de compreensão do fragmento. Articulá-lo com a tradição mítica não melhora o entendimento, pois, no máximo, o situa no âmbito das exortações à manutenção da ordem disposta e mantida pelos deuses e não distingue o pensador dos poetas.

A melhor maneira de compreender um extrato de texto é procedendo a uma investigação de suas partes, buscando algum subsídio que lhe abra o sentido. Um exame dos outros fragmentos do pensador se mostra como único recurso disponível diante da fragmentação de sua obra. A palavra hybris não aparece nos outros fragmentos do efésio. Entretanto, o termo métron, que remete dicotomicamente à hybris, pode ser encontrado mais de uma vez nos textos de Heráclito. Afinal, para poder rechaçar a desmedida com propriedade, é necessário que o pensador exponha o que entende por medida. Os fragmentos mais importantes e - claros - acerca do métron são o 94 e o 30. Este último, preservado por Clemente de Alexandria em seu Stromata, ${ }^{32}$ afirma que: "o cosmo, o mesmo para todos, não o fez nenhum dos deuses nem nenhum dos homens, mas sempre foi, é e será fogo sempre vivo, acendendo-se segundo métra e segundo métra apagando-se". Aqui, Heráclito trata do kósmos, entendido como o "mundo igual para todos" buscando expor a sua configuração, dependente de "medidas" para realizar-se, isto é, "apagar-se" e "acender-se". A hybris do fragmento 43 seria uma exortação à observância dessas medidas cósmicas. O 94, guardado por Plutarco em seu Do exílio ${ }^{33}$, apenas o confirma e também demonstra a proximidade do efésio das cosmogonias míticas: "o Sol não excederá as métra", afirma Heráclito, "se o fizer, as Eríneas, servas da justiça, hão de o encontrar”.

Entretanto, de que forma o homem poderia ultrapassar o métron cósmico se este o transcende, diferentemente do Sol, por exemplo? Se este é mesmo o caso, por que Heráclito se preocupava com a questão? Eugen Fink defende, nos seminários de inverno da Universidade de Friburgo sobre o efésio realizados entre 1966 e 67 e em parceria com Martin Heidegger, que "medidas significam aqui [fragmento 94], no entanto, não leis naturais, mas dizem respeito à physis de Helios" (HEIDEGGER; FINK, 1993, p. 40). Daí porque "a constância do sol no seu caminho diário e anual deriva da sua physis. Helios se mantém preso às medidas de seu caminho por sua própria essência" (HEIDEGGER; FINK, 1993, p. 40). As métra remetem à própria physis das coisas, isto é, à sua natureza ou essência. Por analogia,

\footnotetext{
${ }^{26}$ Vidas e doutrinas dos filósofos ilustres, Livro IX, 2.

${ }^{27}$ Cf. HERÁCLITO. Fragmentos Contextualizados. Trad. Alexandre Costa. São Paulo: Odysseus Editora, 2012, p. 67 , nota 84 .

28 Cf. Emanuel Carneiro Leão em ANAXIMANDRO, PARMÊNIDES E HERÁCLITO. Pensadores Originários. Petrópolis: Vozes, 1999.

${ }^{29}$ Cf. Gerd Borheim em Os Filósofos Pré-Socráticos. São Paulo: Cultrix, 1999 e Jean-François Pradeau em HÉRACLITE. Fragments [Citations et témoignages]. Paris: GF Flamarion, 2004.

${ }^{30}$ Cf. José Cavalcante de Souza em Pré-Socráticos - Os Pensadores. São Paulo: Nova Cultural, 1996 e Mario da Gama Kury em DIÔGENES LAÊRTIOS. Vidas e Doutrinas dos Filósofos Ilustres. Brasília: UNB.

31 Cf. Jean Voilquin em LE PENSEURS GRECS AVANT SOCRATE DE THALES DE MILET À PRODICOS. Paris: GF Flamarion, 1964.

${ }^{32}$ Stromata V, capítulo 14, p. 104.

${ }^{33}$ Do exílio, 604, 5.
} 
poder-se-ia compreender do mesmo modo a ligação do kósmos ao métron, exposta no fragmento 30. A medida de algo seria, no fundo, o seu próprio ser. Heidegger, em Heráclito, obra que contém os cursos de semestre de verão de 1943 e 1944 ministrados pelo filósofo alemão sobre os fragmentos do efésio, corrobora a posição que aproxima medida e natureza das coisas:

\begin{abstract}
O sentido fundamental, ou seja, a essência de métron é a amplitude, o aberto, a clareira que se estende e amplia. [...] O arranjo originário, o kósmos é o doador de medida. A medida que o kósmos dá é o próprio cosmo como physis. Como surgimento, a physis propicia uma "medida", uma amplitude. O sempre surgir do kósmos só pode propiciar essa medida porque o "fogo", pīr (pháos), vigora em si mesmo como physis (HEIDEGGER, 2002a, p. 181-182).
\end{abstract}

Se a medida das coisas remete à sua própria natureza, doada e mantida pela ordenação cósmica, como defende Heidegger, o fragmento 43 começa a fazer sentido filosófico. "Apagar" a hybris seria urgente porque a atitude conspiraria contra a própria natureza humana, uma vez que o homem correria o risco de deixar de ser o que é se rompesse com sua medida. No entanto, permanecem ainda indeterminados o que sejam esse métron humano e sua relação com o kósmos. Três outros fragmentos 50, 45 e 1 poderiam lançar alguma luz sobre a medida do homem, de acordo com Heráclito. O de número 1 diz, seguindo Sexto Empírico em Contra os matemáticos ${ }^{34}$, que

desse lógos, sendo sempre, são os homens ignorantes tanto antes de ouvir como depois de o ouvirem; todas as coisas vêm a ser segundo esse lógos, e ainda assim parecem inexperientes, embora se experimentem nestas palavras e ações, tais quais eu exponho, distinguindo cada coisa segundo a natureza e enunciando como se comporta.

Sexto não se limitou a preservar o fragmento. O contexto de onde foi extraído inclui uma interpretação do filósofo acerca da sentença de Heráclito: "Este lógos universal e divino, do qual participamos e pelo qual nos tornamos seres dotados de lógos, é o critério da verdade, segundo Heráclito" "35. A interpretação de Sexto aparece quase setecentos anos após o florescimento do filósofo conhecido como "o obscuro", o que não chega a ser um argumento a favor da compreensão do médico e filósofo do século II d. C., mas tampouco invalida a sua interpretação. O fragmento afirma serem os homens no lógos, mesmo sem o perceberem. Sexto vai além e argumenta que participamos dele, ou seja, de seu caráter "universal e divino". O homem, segundo Heráclito, é no lógos, pois, de acordo com filósofo cético, participa dele.

O fragmento 45, guardado por Diógenes Laércio nas Vidas e doutrinas dos filósofos ilustres, torna a estruturação supracitada ainda mais nítida: "não encontrarias os limites da alma, mesmo todo o caminho percorrendo, tão profundo lógos possui" "36. A alma, a psyche, possui também um lógos, segundo Heráclito. Existiriam, com efeito, dois lógoi: um humano e outro cósmico. Entre eles, uma relação que liga o homem ao todo, como sinaliza o fragmento 50, preservado por Hipólito, na Refutação ${ }^{37}$ : "ouvindo não a mim, mas ao lógos, é sábio concordar ser tudo-um". Este extrato da obra de Heráclito é tido por Heidegger como central para a compreensão do fragmento 43 e, por extensão, dos fenômenos da hybris e do métron. De acordo com o pensador alemão, a palavra homologeìn, vertida aqui para o português como

\footnotetext{
${ }^{34}$ Contra os matemáticos, VII, 132-133. Cf. HERÁCLITO. Fragmentos contextualizados. Trad. Alexandre Costa. São Paulo, Odysseus, 2012.

${ }^{35}$ Ibid.

${ }^{36}$ Vidas e doutrinas dos filósofos ilustres, Livro IX, 73.

${ }^{37}$ Refutação, IX, 9 e 10.
} 
"concordar", é a chave para a compreensão de toda a argumentação de Heráclito. Heidegger, com efeito, vê o fenômeno como escuta, atenção ao lógos, pois o homologeìn heraclítico ocorreria "quando o légein dos mortais concorda com o Lógos" e, assim, "dá-se e acontece homologeīn" (HEIDEGGER, 2002b, p. 195). A partir de uma leitura dos fragmentos 50 e 45 , Heidegger defende a existência de um lógos humano, encontrado na psichē e outro no kósmos, o Lógos. Em Heráclito, o pensador alemão demonstra a relação entre esses elementos:

\footnotetext{
O próprio homem, enquanto o ente que é, deve "possuir" no cerne de sua essência um lógos que, enquanto lógos, é a "relação" com "o Lógos" no sentido do ser dos entes". De acordo com a concepção grega, o homem é um zōon - um ser vivo. A essência do vivo é, porém, a psiche - a alma. No caso da possibilidade de um homologeìn, a essência do homem, ou seja, a psiche, deve possuir um lógos. Presumivelmente, esse lógos humano deve ser especial, uma vez que nele deve se tecer e vigir a referência a "o Lógos" (HEIDEGGER, 2002a, p. 303).
}

Agora fica livre o caminho para a compreensão do métron e da hybris no pensamento de Heráclito via Heidegger. Se a natureza do homem, sua alma, é lógos e participa do Lógos em um homologeìn, uma escuta vinculante, a medida do homem é a sua relação com ambas as estruturas "lógicas". Segundo Jean-François Pradeau (2004, p. 67), e para defender a hipótese cosmológica de uma razão (lógos) inerente às coisas, "sugere-se que esta última é a medida (métron), realmente a lei (nomos) do universo: a razão cósmica que rege a estrutura objetiva do movimento e da transformação de todas as coisas". Estar na medida é, com efeito, respeitar o próprio ser, realizando o que é próprio dele. Quando Heráclito exorta os homens a apagar a hybris, não é outro o seu objetivo. Afinal, e como afirma Heidegger, "se o homem deve poder atentar ao ser e ouvir o lógos, ele deve, primeiramente, apagar a desmedida e as suas labaredas [...]. Esta [hybris] só se extingue mediante a ausculta obediente [homologeīn] ao lógos" (HEIDEGGER, 2002a, p. 395).

Ao entender a hybris como um fenômeno que depõe contra o lógos, Heráclito se mostra como a fonte de inspiração para as considerações de Platão e de Aristóteles acerca do fenômeno. Apesar da influência da tradição mítica, que atinge os três pensadores, o problema da hybris ganha roupagem nova a partir da filosofia, superando o caráter meramente moral e jurídico ao abarcar a questão de forma mais ampla, indo do cosmológico até o psicológico, passando pelo político. A questão levantada anteriormente por Sólon e pelos poetas trágicos sobre um critério para a ação humana, isto é, sua medida, encontra, com Heráclito, finalmente, sua primeira formulação realmente objetiva: agir de acordo com o lógos.

\section{REFERÊNCIAS}

ABBAGNANO, Nicola. História da filosofia. Vol. 1. Trad. António Borges Coelho, Franco de Sousa e Manuel Patrício. Lisboa: Editorial Presença, 1999.

ANAXIMANDRO. Fragmentos. Trad. José Cavalcante de Souza In: Pré-Socráticos - Os Pensadores. São Paulo: Nova Cultural, 1996.

ANAXIMANDRO, PARMÊNIDES E HERÁCLITO. Pensadores originários. Trad. Emanuel Carneiro Leão. Petrópolis: Vozes, 1999. 
BORNHEIM, Gerd (Org.). Os filósofos pré-socráticos. Trad. Gerd Borheim. São Paulo: Cultrix, 1999.

ARISTOTE. Éthique à Nicomaque. Trad. Jean Tricot. Paris: Vrin, 2012.

La politique. Trad. Jean Tricot. Paris: Vrin, 2005.

ARISTOTLE. Aristotle's Ethica Nicomachea. Ed. J. Bywater.Oxford: Clarendon Press, 1894.

ARISTOTLE. Politics. In: Aristotle in 23 Volumes (v. 20). Trans. H. Rackham. Cambridge, MA/London: Harvard University Press/William Heinemann, 1952a.

. Virtues and vices. In: Aristotle in 23 Volumes (v. 20). Trans. H. Rackham. Cambridge, MA/London: Harvard University Press/William Heinemann, 1952b.

ARISTÓTELES. Ethica Nicomachea - Tratado da virtude moral. Trad. Marco Zingano. São Paulo: Odysseus, 2008.

CASAS, Javier Picón. La Noción de "Hybris" en el Critias de Platón. Areté - Revista de Filosofía, Salamanca, Vol. XX, No 1, p. 75-110, 2008.

CLEMENTE DE ALEXANDRIA. Stromata. In: Stromata IV-V, Martírio Cristiano e Investigación Sobre Dios. Madrid: Editorial Ciudad Nueva, 2003.

DIÔGENES LAÊRTIOS. Vidas e doutrinas dos filósofos ilustres. Trad. Mario da Gama Kury. Brasília: UNB, 1987.

HEIDEGGER, Martin. Heráclito. Trad. Márcia Sá Cavalcante Schuback. Rio de Janeiro: Relume Dumará, 2002a

Lógos (Heráclito, Fragmento 50). In: Ensaios e Conferências. Trad. Emanuel Carneiro Leão. Petrópolis, RJ: Vozes, $2002 b$.

HEIDEGGER, Martin \& FINK, Eugen. Heraclitus seminar. Trans. Charles H. Seibert. Evanston: Northwestern University Press, 1993.

HÉRACLITE. Fragments [Citations et témoignages]. Trad. Jean-François Pradeau. Paris: GF Flamarion, 2004.

HERÁCLITO. Fragmentos contextualizados. Trad. Alexandre Costa. São Paulo: Odysseus Editora, 2012.

- Fragmentos. Trad. José Cavalcante de Souza In: Pré-Socráticos - Os Pensadores. São Paulo: Nova Cultural, 1996.

HYPPOLYTUS OF ROME, The refutation of all heresies. Trans. John Henry MacMahon. Pickerington: Beloved Publishing, 2016.

LE PENSEURS GRECS AVANT SOCRATE DE THALES DE MILET À PRODICOS. Trad. Jean Voilquin. Paris: GF Flamarion, 1964. 
LIDDELL, Henry George; SCOTT, Robert. A greek-english lexicon. Oxford, Claredon Press: 1996.

PLATÃO. A República. Trad. Maria Helena da Rocha Pereira. Lisboa: Fundação Calouste Gulbenkian, 1993. . As Leis. Trad. Edson Bini. São Paulo: Edipro, 1999. Fedão. In: Protágoras, Górgias, Fedão. Trad. Carlos Alberto Nunes. Belém: EDUFPA, 2002.

. Fedro. In: Fedro, Cartas, O Primeiro Alcibíades. Trad. Carlos Alberto Nunes. Belém: EDUFPA, 2007. . Filebo. Tradução de Fernando Muniz. Rio de Janeiro: Editora PUC-Rio; São Paulo: Edições Loyola, 2012.

Górgias. In: Protágoras, Górgias, Fedão. Trad. Carlos Alberto Nunes. Belém: EDUFPA, 2002.

PLATO. Platonis opera, Ed. John Burnet. Oxford: Oxford University Press, 1903.

PLUTARCH. On exile. In: Moralia. Vol. VII. Trans. Phillip H. De Lacy and Benedict Einarson. Cambridge: Loeb Classical Library, 1959. 